Review

\title{
Development of Vitamin D Toxicity from Overcorrection of Vitamin D Deficiency: A Review of Case Reports
}

\author{
Kornelia Galior, Stefan Grebe and Ravinder Singh * \\ Department of Laboratory Medicine and Pathology, Mayo Clinic, Rochester, MN 55905, USA; \\ Galior.Kornelia@mayo.edu (K.G.); Grebe.Stefan@mayo.edu (S.G.) \\ * Correspondence: Singh.Ravinder@mayo.edu; Tel.: +1-507-766-0481
}

Received: 5 June 2018; Accepted: 16 July 2018; Published: 24 July 2018

\begin{abstract}
Over the past two decades, vitamin D level measurements have become some of the most frequently ordered tests in the laboratory. This increase is due to a growing awareness of widespread vitamin D deficiency and scientific data suggesting the beneficial effects of vitamin D in various diseases. A literature search was carried out in PubMed for cases reporting vitamin D intoxication and overdose. Thirteen articles were included in this review. Intoxication was severe in the reported cases. Patients presented with serum vitamin D concentrations ranging between 150 and $1220 \mathrm{ng} / \mathrm{mL}$ and serum calcium concentrations between 11.1 and $23.1 \mathrm{mg} / \mathrm{dL}$. Most of the reported patients showed symptoms of vitamin $\mathrm{D}$ toxicity such as vomiting, dehydration, pain, and loss of appetite. The underlying causes included manufacturing errors, overdosing by patients or prescribers, and combinations of these factors. Our literature search highlights the fact that even though vitamin D intoxication is rare, it does occur and therefore patients and prescribers should be more cognizant of the potential dangers of vitamin D overdose.
\end{abstract}

Keywords: vitamin D toxicity; vitamin D overdose; hypercalcemia

\section{Introduction}

Over the past two decades, interest in vitamin D has increased significantly. Besides playing important roles in calcium homeostasis and bone mineralization, vitamin D is now recognized as playing a role in the immune system, cardiovascular health, and cancer prevention [1-3]. Based on guidelines by the Institute of Medicine, recommended dietary allowances for vitamin D are $600 \mathrm{IU} /$ day for those aged between 1 and 70 years and $800 \mathrm{IU} /$ day for those aged 71 and above [4]. For babies below one year of age, the American Academy of Pediatrics recommends $400 \mathrm{IU} /$ day [5]. These dietary recommendations should result in serum 25-hydroxyvitamin D levels of $\geq 20 \mathrm{ng} / \mathrm{mL}$. At the other end of the scale, the Food and Nutrition Board has set upper intake levels of vitamin D at $2000 \mathrm{IU} /$ day (50 $\mathrm{\mu g}$ /day) [6]. Doses higher than 50,000 IU/day raise serum concentrations above $150 \mathrm{ng} / \mathrm{mL}$, leading to hypercalcemia [7].

With vitamin D deficiency being implicated in an increasing number of diseases $[2,4,8,9]$, requests for serum vitamin D concentration measurements increased between the year 2000 and 2010 by over 80-fold [10]. The total 25-hydroxyvitamin D (25(OH)D) level, which includes both exogenous and endogenous vitamin $\mathrm{D}$, is an appropriate indicator of the vitamin $\mathrm{D}$ that the body stores. Although there is no universal consensus about a treatment cut-off level, studies suggest 25 to $35 \mathrm{ng} / \mathrm{mL}$ as the minimum concentration of $25(\mathrm{OH}) \mathrm{D}$ needed to avoid adverse effects of deficiency, a problem particularly common at high latitudes, especially in the winter [11,12]. Suggestions to maintain vitamin D sufficiency include exposure to sunlight (the skin produces up to 10,000 IU/day after exposure to UV 
light), fortified foods (e.g., milk is fortified with $100 \mathrm{IU} /$ cup), and over-the-counter supplementation (1000-2000 U/day). In addition, vitamin D is mostly found in fatty fish (447-1360 IU/100 g) and mushrooms $[13,14]$. However, vitamin D treatment is not without risks, as vitamin D toxicity has potentially serious consequences $[15,16]$. Due to a wide therapeutic index, vitamin D overdose is rare, but it does occur at excessively high doses. Vitamin D intoxication can be iatrogenic due to manufacturing errors or self-administration. In this report, cases of patients who had received high doses of vitamin $\mathrm{D}$ were reviewed and presented to describe features of vitamin D toxicity.

\section{Materials and Methods}

This review is based on a Pubmed search for articles published between 1936 and 2018 that described cases of vitamin D toxicity. The following terms were included in the search: 'vitamin D toxicity cases', 'vitamin D intoxication cases', and 'vitamin D overdose cases'. These criteria identified 85 publications. After examining the title, abstract, and laboratory findings, 13 publications which reported the amount of vitamin D intake, serum vitamin D concentration upon admission, and a complete medical evaluation of the patient were included in the final analysis. Publications that were rejected included review papers $(n=21)$, animal studies $(n=16)$, cases not related to vitamin $\mathrm{D}$ intoxication $(n=29)$, cases of malignancy-associated hypercalcemia $(n=5)$, and a case of supposed vitamin $\mathrm{D}$ toxicity $(n=1)$ without any convincing laboratory data to support this diagnosis.

The Advanced Cohort Explorer (ACE) was used to generate the number of vitamin D tests ordered from the Mayo Clinic in Rochester, MN, USA between 1994 and 2017. The ACE is a clinical data repository maintained by the Unified Data Platform which contains patient information such as patient demographics, diagnoses, laboratory tests, and clinical notes. Data was obtained from multiple clinical and hospital source systems within the Mayo Clinic Rochester.

\section{Results and discussion}

In the last two decades, many laboratories have experienced a surge in demand for vitamin $\mathrm{D}$ testing (Figure 1).

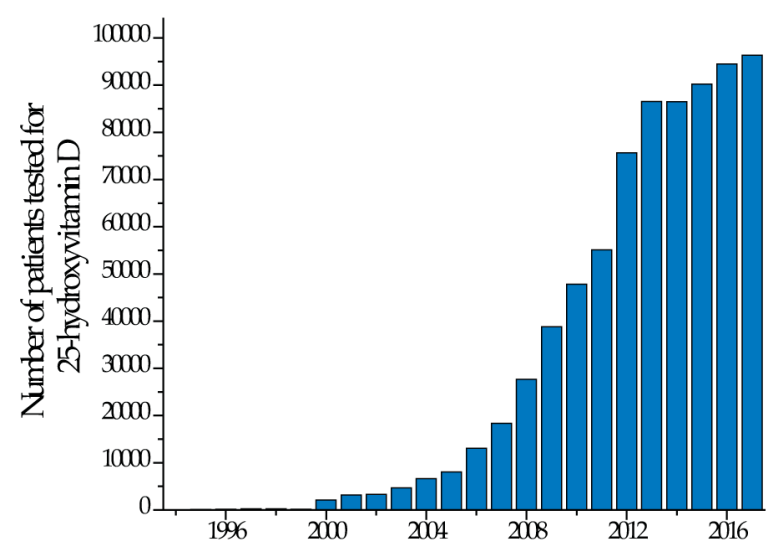

Figure 1. Sustained increase in testing volumes of vitamin D at the Mayo Clinic.

As more patients are tested, an increasing number of individuals with elevated serum $25(\mathrm{OH}) \mathrm{D}$ levels have been identified. Vitamin D toxicity occurs from exposure to extremely high doses of vitamin D supplementation, which can be the result of manufacturing errors or accidental or intentional incorrect dosing $[15,17]$. It is important to emphasize that supplementation is usually driven more by patients than physicians. Since vitamin D increases calcium absorption in the gastrointestinal tract, vitamin D intoxication manifests primarily as hypercalcemia and hypercalciuria. This leads potentially to muscle weakness, hypertension, neuropsychiatric disturbances, gastrointestinal upset, polyuria and polydipsia, renal calculi, and, in extreme cases, renal failure, deposition of calcium phosphate crystals 
in soft tissues throughout the body, cardiac arrhythmias (reduced action potential), calcification of coronary vessels and heart valves, and ultimately, death [18,19].

Various cut-off values for the upper levels of serum vitamin D are used across the USA [4,20,21]. However, the patients listed in Table 1 had levels above all cut-off values in common use. The table summarizes the presented cases and includes patients' age, vitamin D dose, vitamin D test results, and total calcium levels.

\subsection{Manufacturing Errors}

Vitamin D intoxication with severe hypercalcemia has been reported in adult and pediatric cases due to manufacturing errors of dietary supplements and are summarized in Table 1. Anik et al. and Kara et al. described 10 children aged between one and four years who were admitted to the hospital with symptoms of abdominal pain, vomiting, dehydration, and poor appetite [22,23]. In two children, renal ultrasonography showed the development of bilteral nephrocalcinosis. Laboratory findings showed total calcium results between 13.4 and $19.4 \mathrm{mg} / \mathrm{dL}$ (normal range 8.4-10.2 mg/dL) and serum 25(OH)D between 340 and $962 \mathrm{ng} / \mathrm{mL}$ (normal range $25-80 \mathrm{ng} / \mathrm{mL}$ ). The medical history and conversations with the parents revealed that all children were supposed to be receiving 200 IU of vitamin D each day for up to one month as a dietary supplement to improve appetite. Laboratory analysis of the supplements showed that the actual vitamin D content was 4000 times the labeled concentration. As a result, the children had been ingesting between 266,000 and 800,000 IU each day without any investigation for a specific diagnosis.

Araki et al. reported two adult cases of vitamin D intoxication with dietary supplements due to manufacturing errors that resulted in 1000-fold higher levels of vitamin D [24]. Laboratory findings in the patients upon admission showed 25(OH)D levels between 654 and $1220 \mathrm{ng} / \mathrm{mL}$ (normal range $30-80 \mathrm{ng} / \mathrm{mL}$ ) and total calcium between 13.2 and $15.0 \mathrm{mg} / \mathrm{dL}$ (normal range 8.4-10.2 mg/dL).

Koutkia et al. described a 42-year-old male who presented with classic symptoms of hypercalcemia, serum 25(OH)D levels of $487.3 \mathrm{ng} / \mathrm{mL}$, and total calcium of $15.0 \mathrm{mg} / \mathrm{dL}$ [25]. Analysis of the supplement by HPLC revealed that the actual dose that the patient had been taking was 78-1302 times the recommended upper limit of $2000 \mathrm{IU} / \mathrm{d}$.

\subsection{Inappropriate Administration}

In 2015, Ketha et al. reported a pediatric case of vitamin D intoxication with vitamin D supplements [26]. An infant was admitted to the hospital with significant dehydration, vomiting, constipation, lethargy, and weight loss. Routine biochemical evaluation demonstrated total calcium levels of $18.7 \mathrm{mg} / \mathrm{dL}$, indicating severe hypercalcemia. Vitamin D metabolites were tested in the infant's blood and were as follows: $25(\mathrm{OH}) \mathrm{D}_{3}, 293 \mathrm{ng} / \mathrm{mL}$ (optimal range of total 25(OH)D: 20-50 ng $/ \mathrm{mL}$ ); and $1,25(\mathrm{OH})_{2} \mathrm{D}_{3}, 138 \mathrm{pg} / \mathrm{mL}$ (optimal range: $24-86 \mathrm{pg} / \mathrm{mL}$ ). Renal ultrasonography revealed nephrocalcinosis. A detailed discussion with the mother revealed that the infant was receiving $50,000 \mathrm{IU}$ of vitamin D per day, while the recommended dose on the label was $2000 \mathrm{IU}$.

Two other case reports of breastfed infants who had vitamin D toxicity were described by Bilbao [27]. The two infants (aged 2.5 months and 3.5 months, respectively) were admitted to the hospital with an identical presentation, including decreased feeding, lethargy, moderate dehydration, and inconsolable crying. Both infants were exclusively breastfed and had been receiving over-the-counter vitamin D supplementation. During the discussion with the parents, it was revealed that the infants had received vitamin D supplementation far above the recommended dose, resulting in hypervitaminosis D (25(OH)D: 644-680 $\mathrm{ng} / \mathrm{mL}$ ) and hypercalcemia (total calcium: 15-21 mg/dL).

Rocha and Santos reported the case of a 19-year-old male who used a parenteral formulation of vitamins $\mathrm{A}, \mathrm{D}$, and $\mathrm{E}$ restricted to veterinary use $\left(5,000,000 \mathrm{IU}\right.$ of vitamin $\mathrm{D}_{3}$ in a $100-\mathrm{mL}$ vial) [28]. The patient was admitted to the hospital with a three-week history of anorexia, nausea, and vomiting. Serum 25(OH)D was found to be $150 \mathrm{ng} / \mathrm{mL}$ and total calcium was found to be $14.8 \mathrm{mg} / \mathrm{dL}$. He later admitted taking $300 \mathrm{~mL}$ of the product over one year in order to give the impression of bigger 
muscles through the swelling of the tissue after injecting the oily formulation. Treatment of the patient included normal saline, furosemide, and zoledronic acid that rapidly normalized calcium levels and renal function.

\subsection{Incorrect Prescribing by Physicians}

Physicians treat patients with high doses of vitamin D for various disorders and in some instances, prescribe doses that exceed the suggested recommendations. Kaur et al. and Koul et al. described patients who were prescribed high doses of vitamin D supplements for various ailments [29,30]. Patients with ages ranging from 42 to 86 years presented with clinical features of vitamin D overdose: lethargy $(n=3)$, vomiting $(n=9)$, polyuria $(n=5)$, polydipsia $(n=5)$, altered sensorium $(n=9)$, renal dysfunction $(n=5)$, weight loss $(n=5)$, nausea $(n=5)$, and constipation $(n=4)$. Laboratory tests revealed hypercalcemia in all of these patients, with serum calcium level between 11.0 and $15.7 \mathrm{mg} / \mathrm{dL}$, serum phosphates ranging from 2.0 to $8.6 \mathrm{mg} / \mathrm{dL}$ (normal range 3.5-5.0), and serum 25(OH)D between 164 and $1161 \mathrm{ng} / \mathrm{mL}$. Differential diagnosis of hypercalcemia included multiple myeloma, granulomatous disease, renal disease, and hyperparathyroidism, but based on further evaluations, these diseases were ruled out. It was determined that the patients had taken 2,220,000-60,000,000 IU of vitamin D over a period of 4-7 weeks for various conditions that included back pain $(n=4)$, radiculopathy $(n=2)$, osteoarthritis $(n=2)$, or generalized weakness $(n=2)$. These megadoses resulted in vitamin D toxicity in all patients. Treatment of hypercalcemia included steroids, bisphosphonates, and calcitonin. Eventually clinical recovery of these patients was observed.

Bansal also described an iatrogenic case of hypervitaminosis D [31]. It involved a 45-year-old female who had received a total of 6,000,000 IU of vitamin D as an intramuscular injection within a period of two weeks. The patient was admitted to the hospital with a history of recurrent vomiting, pain in her abdomen, polydipsia, anorexia, and constipation over the previous 1.5 months. Laboratory results revealed $25(\mathrm{OH}) \mathrm{D}$ and total calcium levels to be $150 \mathrm{ng} / \mathrm{mL}$ and $23.1 \mathrm{mg} / \mathrm{dL}$, respectively. It was later revealed that the intramuscular injection had been prescribed after her knee surgery. The hypercalcemia was treated with intravenous fluid, diuretics, and calcitonin, and the high serum calcium normalized within 15 days.

Iatrogenic hypervitaminosis D was reported in elderly subjects in whom toxicity occurred due to excessive administration of vitamin $\mathrm{D}$ by oral and intramuscular routes [32]. The injections of vitamin $\mathrm{D}$ (600,000 IU/injection) were prescribed by the physician to improve health and to reduce the frailty of the elderly. Fifteen patients aged between 42 and 85 years presented to the hospital with elevated serum calcium and serum 25(OH)D levels. Median (range) serum 25(OH)D levels and median (range) total serum calcium levels were 118.1 (103-164) ng/mL and 13 (10.9-15.1) mg/dL, respectively. Clinical symptoms upon admission included altered sensorium (82.4\%), dehydration (88.2\%), vomiting (35.3\%), anorexia (70.6\%), fatigue (82.4\%), generalized body weakness $(88.2 \%)$, constipation (52.9\%), polyuria (76.5\%), and polydipsia (70.6\%). Among the 15 cases, 12 showed evidence of renal dysfunction.

Chowdry reported on 19 patients aged between 45 and 89 years with vitamin D toxicity-induced acute kidney injury (AKI) [33]. Clinical manifestations upon admission to the hospital included nausea and vomiting $(n=11)$, altered sensorium $(n=7)$, constipation $(n=9)$, acute pancreatitis $(n=2)$, AKI $(n=16)$, acute chronic kidney disease $(n=3)$, and weight loss $(n=2)$. The median serum calcium level was $13.0 \mathrm{mg} / \mathrm{dL}$, with the lowest concentration being $11.9 \mathrm{mg} / \mathrm{dl}$ and highest concentration of $15.2 \mathrm{mg} / \mathrm{dl}$. The median serum 25(OH)D concentration was $371 \mathrm{ng} / \mathrm{ml}$, with the lowest concentration being $190 \mathrm{ng} / \mathrm{ml}$ and highest concentration being $988 \mathrm{ng} / \mathrm{ml}$. Enteral or parenteral overcorrection of vitamin D deficiency was the cause of vitamin D toxicity-induced AKI in all cases. All the patients were prescribed vitamin $\mathrm{D}$ by their physician for various ailments: bone pains $(n=6)$, generalized aches and pains $(n=6)$, fatigue $(n=5)$, and myalgia $(n=2)$. Management of AKI and hypercalcemia for all patients included intravenous fluids, diuretics, calcitonin, and glucocorticoids. 
Table 1. Test results and dosage information of patients with vitamin D toxicity. AKI: acute kidney injury.

\begin{tabular}{|c|c|c|c|c|c|c|c|}
\hline Age (years) & Vitamin D dose & Form of Intake & Reason & $\begin{array}{c}\text { Vitamin D, } \\
\text { Serum (ng/m) }\end{array}$ & $\begin{array}{l}\text { Total Ca, Serum } \\
(\mathrm{mg} / \mathrm{dL})\end{array}$ & Symptoms & Ref \\
\hline $0.4-4.2(n=7)$ & $260,000-800,000 \mathrm{IU} /$ day & $\begin{array}{c}\text { Fish oil } \\
\text { supplements }\end{array}$ & Labeling errors & $340-962$ & $13.4-18.8$ & $\begin{array}{l}\text { Weakness, loss of } \\
\text { appetite, vomiting }\end{array}$ & {$[23]$} \\
\hline $\begin{array}{c}1-2(n=2) \\
1\end{array}$ & $\begin{array}{l}200 \mathrm{IU} / \text { day (2-4weeks) } \\
200 \mathrm{IU} / \text { day (1 month) }\end{array}$ & $\begin{array}{l}\text { Oral preparation } \\
\text { Oral preparation }\end{array}$ & $\begin{array}{l}\text { Labeling errors } \\
\text { Labeling errors }\end{array}$ & $\begin{array}{c}>160 \\
760\end{array}$ & $\begin{array}{c}13.7-19.3 \\
19.4\end{array}$ & $\begin{array}{l}\text { Abdominal pain, vomiting } \\
\text { Poor appetite, vomiting }\end{array}$ & {$[22]$} \\
\hline $\begin{array}{l}58 \\
40\end{array}$ & $\begin{array}{l}\text { 1,864,000 IU (2 months) } \\
970,000 \text { IU (1 month) }\end{array}$ & $\begin{array}{l}\text { Oral supplements } \\
\text { Oral supplements }\end{array}$ & $\begin{array}{l}\text { Labeling errors } \\
\text { Labeling errors }\end{array}$ & $\begin{array}{c}1220 \\
645\end{array}$ & $\begin{array}{c}15 \\
13.2\end{array}$ & $\begin{array}{l}\text { Fatigue, thirst, polyuria } \\
\text { Nausea, vomiting, thirst, } \\
\text { polyuria, muscle aches }\end{array}$ & {$[24]$} \\
\hline 42 & $\begin{array}{c}156,000-2,604,000 \mathrm{IU} / \text { day } \\
\text { (2 years) }\end{array}$ & Oral supplements & Labeling errors & 487.3 & 15 & $\begin{array}{l}\text { Dehydration, fatigue, } \\
\text { loss of apetite }\end{array}$ & {$[25]$} \\
\hline 0.3 & 50,000 IU/day (2 months) & Oral supplements & $\begin{array}{l}\text { Inappropriate } \\
\text { administration }\end{array}$ & 294 & 18.7 & Vomiting, diarrhea, dehydration & {$[26]$} \\
\hline $0.3-0.2(n=2)$ & 20,000 IU/day (1.5 weeks) & Oral supplements & $\begin{array}{l}\text { Inappropriate } \\
\text { administration }\end{array}$ & $\begin{array}{l}644 \\
680\end{array}$ & $\begin{array}{l}15 \mathrm{~L} \\
21 \mathrm{~L}\end{array}$ & Poor appetite, lethargy, crying & {$[27]$} \\
\hline 19 & 15,000,000 IU (1 year) & Injection & $\begin{array}{l}\text { Inappropriate } \\
\text { administration }\end{array}$ & 150 & 14.8 & Anorexia, nausea, vomiting & {$[28]$} \\
\hline $42-86(n=16)$ & $\begin{array}{l}2,220,000-6,360,000 \mathrm{IU} \\
\text { (1-3 months) }\end{array}$ & $\begin{array}{l}\text { Injection or oral } \\
\text { sachets }\end{array}$ & $\begin{array}{l}\text { Iatrogenic (body aches } \\
\text { and fatigue) }\end{array}$ & $175-1161$ & $11.1-15.7$ & Nausea, vomiting, constipation & [29] \\
\hline $48-75(n=0)$ & $\begin{array}{c}3,000,000-60,000,000 \mathrm{IU} \\
(1-4 \text { months })\end{array}$ & $\begin{array}{l}\text { Injection or oral } \\
\text { sachets }\end{array}$ & $\begin{array}{l}\text { Iatrogenic (various } \\
\text { indications) }\end{array}$ & 164-306 & $12-13.98$ & Vomiting, polyuria, anorexia & {$[30]$} \\
\hline 45 & $6,000,000$ IU (2 weeks) & Injection & $\begin{array}{l}\text { Iatrogenic (knee } \\
\text { surgery) }\end{array}$ & 150 & 23.1 & $\begin{array}{l}\text { Anorexia, vomiting, } \\
\text { abdominal pain }\end{array}$ & {$[31]$} \\
\hline $42-85(n=15)$ & $\begin{array}{c}\text { 600,000 IU ( } 1 \text { month-3 } \\
\text { years) }\end{array}$ & $\begin{array}{l}\text { Oral supplements } \\
+ \text { injections }\end{array}$ & $\begin{array}{l}\text { Iatrogenic (improve } \\
\text { health) }\end{array}$ & $103-164$ & $10.9-15.2$ & $\begin{array}{l}\text { Altered sensorium, dehydration, } \\
\text { vomiting, anorexia }\end{array}$ & {$[32]$} \\
\hline $45-89(n=19)$ & $\begin{array}{l}4,200,000-9,000,000 \mathrm{IU} \\
\text { (1-5 months) }\end{array}$ & $\begin{array}{l}\text { Oral tablets or } \\
\text { injections }\end{array}$ & $\begin{array}{l}\text { Iatrogenic (bone pain, } \\
\text { aches, fatigue) }\end{array}$ & 190-988 & $11.9-15.2$ & $\begin{array}{c}\text { Vomiting, altered sensorium, } \\
\text { AKI, constipation, }\end{array}$ & {$[33]$} \\
\hline 75 & 50,000 IU/day (1 year) & Oral supplements & $\begin{array}{c}\text { Iatrogenic } \\
\text { (hypoparathyroidism) }\end{array}$ & 243 & 15.3 & Altered mental status & {$[34]$} \\
\hline
\end{tabular}




\section{Conclusions}

Vitamin D plays an important role in calcium homeostasis and bone mineralization. Vitamin D also exhibits many non-skeletal effects, particularly in cancer, cardiovascular diseases, and autoimmune diseases. However, inappropriate use of vitamin D supplements can lead to toxicity and life-threating hypercalcemia. Due to a wide therapeutic index, vitamin D toxicity is extremely rare; however, it does occur at excessively high doses. The highest daily intake of vitamin $\mathrm{D}$ that will pose no risk of adverse effects is not known. The current allowable upper intake of vitamin D for long-term supplementation is $2000 \mathrm{IU} /$ day. Here, we show cases where vitamin D toxicity was caused by formulation, administration, subscription errors, which resulted in excessive dosing. The vitamin $\mathrm{D}$ doses reported in these cases ranged from 50,000 IU/day to 2,604,000 IU/day and led to marked hypercalcemia (total calcium between 11.1 and $23.08 \mathrm{mg} / \mathrm{dL}$ ) and serum 25(OH)D concentrations greater than $150 \mathrm{ng} / \mathrm{mL}$. The clinical manifestations of vitamin D toxicity reported in these cases were a consequence of the hypercalcemia and included nausea, vomiting, weakness, polyuria, nephrocalcinosis, and renal failure. This indicates that $25(\mathrm{OH}) \mathrm{D}$ levels above $150 \mathrm{ng} / \mathrm{mL}$ are likely to be associated with toxicity and should be avoided at all costs.

We recommend that more conventional doses of vitamin D supplements, in line with Institute of Medicine and other published guidelines, should be used, unless there is an urgent need for rapid increases in $25(\mathrm{OH}) \mathrm{D}$ levels. In the case of high-dose treatment, extra care should be taken in instructing patients about proper use; they should be instructed to avoid additional over-the-counter supplements, and the number of high doses prescribed should be limited, with 25(OH)D levels being checked regularly.

With regards to over-the-counter supplements, patients should be advised of current dosing recommendations, in particular that $2000 \mathrm{IU} /$ day should not be exceeded in the long term without prior consultation with a physician. They should also be instructed as to symptoms of hypercalcemia and to cease taking supplements if such symptoms occur and have their serum calcium, phosphate, and $25(\mathrm{OH}) \mathrm{D}$ levels measured before resuming supplementation.

Finally, while relatively uncommon, vitamin D intoxication should always be considered as a differential diagnosis when evaluating patients with hypercalcemia.

Author Contributions: All authors critically reviewed the manuscript and contributed to the writing.

Conflicts of Interest: The authors declare no conflict of interest.

\section{References}

1. Delvin, E.; Souberbielle, J.C.; Viard, J.P.; Salle, B. Role of vitamin D in acquired immune and autoimmune diseases. Crit. Rev. Clin. Lab. Sci. 2014, 51, 232-247. [CrossRef] [PubMed]

2. Brewer, L.C.; Michos, E.D.; Reis, J.P. Vitamin D in atherosclerosis, vascular disease, and endothelial function. Curr. Drug Targets 2011, 12, 54-60. [CrossRef] [PubMed]

3. Rizzoli, R. Nutritional aspects of bone health. Best Pract. Res. Clin. Endocrinol. Metab. 2014, 28, 795-808. [CrossRef] [PubMed]

4. Ross, A.C.; Manson, J.E.; Abrams, S.A.; Aloia, J.F.; Brannon, P.M.; Clinton, S.K.; Durazo-Arvizu, R.A.; Gallagher, J.C.; Gallo, R.L.; Jones, G.; et al. The 2011 report on dietary reference intakes for calcium and vitamin D from the Institute of Medicine: What clinicians need to know. J. Clin. Endocrinol. Metab. 2011, 96, 53-58. [CrossRef] [PubMed]

5. Glade, M.J. A 21st century evaluation of the safety of oral vitamin D. Nutrition 2012, 28, 344-556. [CrossRef] [PubMed]

6. Hathcock, J.N.; Shao, A.; Vieth, R.; Heaney, R. Risk assessment for vitamin D. Am. J. Clin. Nutr. 2007, 85, 6-18. [CrossRef] [PubMed]

7. Vieth, R. Why the optimal requirement for Vitamin D3 is probably much higher than what is officially recommended for adults. J. Steroid Biochem. Mol. Biol. 2004, 8, 575-579. [CrossRef] [PubMed] 
8. Holick, M.F.; Binkley, N.C.; Bischoff-Ferrari, H.A.; Gordon, C.M.; Hanley, D.A.; Heaney, R.P.; Murad, M.H.; Weaver, C.M.; Endocrine, S. Evaluation, treatment, and prevention of vitamin D deficiency: An Endocrine Society clinical practice guideline. J. Clin. Endocrinol. Metab. 2011, 96, 1911-1930. [CrossRef] [PubMed]

9. Chu, M.P.; Alagiakrishnan, K.; Sadowski, C. The cure of ageing: Vitamin D-magic or myth? Postgrad. Med. J. 2010, 86, 608-616. [CrossRef] [PubMed]

10. Shahangian, S.; Alspach, T.D.; Astles, J.R.; Yesupriya, A.; Dettwyler, W.K. Trends in laboratory test volumes for Medicare Part B reimbursements, 2000-2010. Arch. Pathol. Lab. Med. 2014, 138, 189-203. [CrossRef] [PubMed]

11. Holick, M.F. Deficiency of sunlight and vitamin D. BMJ Br. Med. J. 2008, 336, 1318. [CrossRef] [PubMed]

12. Galior, K.; Ketha, H.; Grebe, S.; Singh, R.J. 10 years of 25-hydroxyvitamin-D testing by LC-MS/MS-trends in vitamin-D deficiency and sufficiency. Bone Rep. 2018, 8, 268-273. [CrossRef] [PubMed]

13. Lehmann, U.; Gjessing, H.R.; Hirche, F.; Mueller-Belecke, A.; Gudbrandsen, O.A.; Ueland, P.M.; Mellgren, G.; Lauritzen, L.; Lindqvist, H.; Hansen, A.L.; et al. Efficacy of fish intake on vitamin D status: A meta-analysis of randomized controlled trials. Am. J. Clin. Nutr. 2015, 102, 837-847. [CrossRef] [PubMed]

14. Keegan, R.J.; Lu, Z.; Bogusz, J.M.; Williams, J.E.; Holick, M.F. Photobiology of vitamin D in mushrooms and its bioavailability in humans. Dermatoendocrinol 2013, 5, 165-176. [CrossRef] [PubMed]

15. Lee, J.P.; Tansey, M.; Jetton, J.G.; Krasowski, M.D. Vitamin D Toxicity: A 16-Year Retrospective Study at an Academic Medical Center. Lab. Med. 2018, 49, 123-129. [CrossRef] [PubMed]

16. Spiller, H.A.; Good, T.F.; Spiller, N.E.; Aleguas, A. Vitamin D exposures reported to US poison centers 2000-2014: Temporal trends and outcomes. Hum. Exp. Toxicol. 2016, 35, 457-461. [CrossRef] [PubMed]

17. Taylor, P.N.; Davies, J.S. A review of the growing risk of vitamin D toxicity from inappropriate practice. Br. J. Clin. Pharmacol. 2018, 84, 1121-1127. [CrossRef] [PubMed]

18. Ahmed, R.; Hashiba, K. Reliability of QT intervals as indicators of clinical hypercalcemia. Clin. Cardiol. 1988, 11, 395-400. [CrossRef] [PubMed]

19. Minisola, S.; Pepe, J.; Piemonte, S.; Cipriani, C. The diagnosis and management of hypercalcaemia. BMJ 2015, 350, h2723. [CrossRef] [PubMed]

20. Alshahrani, F.; Aljohani, N. Vitamin D: Deficiency, sufficiency and toxicity. Nutrients 2013, 5, 3605-3616. [CrossRef] [PubMed]

21. Bischoff-Ferrari, H.A. Optimal serum 25-hydroxyvitamin D levels for multiple health outcomes. Adv. Exp. Med. Biol. 2014, 810, 500-525. [PubMed]

22. Anik, A.; Catli, G.; Abaci, A.; Dizdarer, C.; Bober, E. Acute vitamin D intoxication possibly due to faulty production of a multivitamin preparation. J. Clin. Res. Pediatr. Endocrinol. 2013, 5, 136-139. [PubMed]

23. Kara, C.; Gunindi, F.; Ustyol, A.; Aydin, M. Vitamin D intoxication due to an erroneously manufactured dietary supplement in seven children. Pediatrics 2014, 133, e240-e244. [CrossRef] [PubMed]

24. Araki, T.; Holick, M.F.; Alfonso, B.D.; Charlap, E.; Romero, C.M.; Rizk, D.; Newman, L.G. Vitamin D intoxication with severe hypercalcemia due to manufacturing and labeling errors of two dietary supplements made in the United States. J. Clin. Endocrinol. Metab. 2011, 96, 3603-3608. [CrossRef] [PubMed]

25. Koutkia, P.; Chen, T.C.; Holick, M.F. Vitamin D intoxication associated with an over-the-counter supplement. N. Engl. J. Med. 2001, 345, 66-77. [CrossRef] [PubMed]

26. Ketha, H.; Wadams, H.; Lteif, A.; Singh, R.J. Iatrogenic vitamin D toxicity in an infant-A case report and review of literature. J. Steroid. Biochem. Mol. Biol. 2015, 148, 14-18. [CrossRef] [PubMed]

27. Bilbao, N.A. Vitamin D Toxicity in Young Breastfed Infants: Report of 2 Cases. Glob. Pediatr. Health 2017, 4, 2333794X17731695. [CrossRef] [PubMed]

28. Rocha, P.N.; Santos, C.S.; Avila, M.O.; Neves, C.L.; Bahiense-Oliveira, M. Hypercalcemia and acute kidney injury caused by abuse of a parenteral veterinary compound containing vitamins A, D, and E. J. Bras. Nefrol. 2011, 33, 467-471. [CrossRef] [PubMed]

29. Kaur, P.; Mishra, S.K.; Mithal, A. Vitamin D toxicity resulting from overzealous correction of vitamin D deficiency. Clin. Endocrinol. 2015, 83, 327-331. [CrossRef] [PubMed]

30. Koul, P.A.; Ahmad, S.H.; Ahmad, F.; Jan, R.A.; Shah, S.U.; Khan, U.H. Vitamin d toxicity in adults: A case series from an area with endemic hypovitaminosis d. Oman Med. J. 2011, 26, 201-204. [CrossRef] [PubMed]

31. Bansal, R.K.; Tyagi, P.; Sharma, P.; Singla, V.; Arora, V.; Bansal, N.; Kumar, A.; Arora, A. Iatrogenic hypervitaminosis D as an unusual cause of persistent vomiting: A case report. J. Med. Case Rep. 2014, 8, 74. [CrossRef] [PubMed] 
32. Pandita, K.K.; Razdan, S.; Kudyar, R.P.; Beigh, A.; Kuchay, S.; Banday, T. "Excess gooD can be Dangerous". A case series of iatrogenic symptomatic hypercalcemia due to hypervitaminosis D. Clin. Cases. Miner. Bone Metab. 2012, 9, 118-120. [PubMed]

33. Chowdry, A.M.; Azad, H.; Najar, M.S.; Mir, I. Acute kidney injury due to overcorrection of hypovitaminosis D: A tertiary center experience in the Kashmir Valley of India. Saudi J. Kidney Dis. Transpl. 2017, 28, 1321-1329. [CrossRef] [PubMed]

34. Kim, S.; Stephens, L.D.; Fitzgerald, R.L. How much is too much? Two contrasting cases of excessive vitamin D supplementation. Clin. Chim. Acta 2017, 473, 35-38. [CrossRef] [PubMed]

(C) 2018 by the authors. Licensee MDPI, Basel, Switzerland. This article is an open access article distributed under the terms and conditions of the Creative Commons Attribution (CC BY) license (http:/ / creativecommons.org/licenses/by/4.0/). 